\title{
Considerații asupra unor forme ale verbului a fi: sum și sunt
}

\author{
Gheorghe Chivu* \\ Facultatea de Litere, Universitatea din București, Str. Edgar Quinet 5-7, Sector 1, 010017 București, România \\ Academia Română, Calea Victoriei 125, Sector 1, 010071 București, România
}

\author{
Despre articol \\ Istoric: \\ Primit 4 iunie 2018 \\ Acceptat 9 iunie 2018 \\ Publicat 7 octombrie 2018 \\ Cuvinte-cheie: \\ limbă română literară \\ normă literară \\ forme verbale culte \\ sum \\ sunt
}

\begin{abstract}
Rezumat
Istoria formelor verbale sum și sunt, introduse în scrisul literar de școala latinistă ardeleană, pune în evidență un proces sinuos de elaborare a unor norme de tip cult în cadrul românei literare moderne. Deloc linear, acest proces a fost influențat concomitent de două tendințe, nu totdeauna convergente, manifestate în scrisul românesc de la sfîrșitul secolului al XVIII-lea pînă la începutul secolului al XX-lea: utilizarea unor forme culte, preluate din latină sau modelate după tipare latinești, respectiv revitalizarea unor fenomene lingvistice cu circulație regională, considerate moștenite din latină.

Propuse inițial ca rostiri literare, cele două forme au fost acceptate și utilizate mult timp ca grafii etimologizante corespunzătoare lui sîm, respectiv suntu, atestate în zone dialectale cu caracter conservator. În a doua jumătate a secolului al XIX-lea (sum), respectiv în primele decenii ale secolului al XX-lea (sunt), cele două grafii au redevenit norme ortoepice, în condițiile predominanței tradiției fonologice în scrisul românesc.
\end{abstract}

I. Școala Ardeleană, cunoscuta mișcare iluministă, a urmărit, pentru prima dată în istoria culturii noastre scrise, în mod programatic, prin lucrări reprezentative pentru ortografie, gramatică şi vocabular, normarea românei literare moderne.

A fost, în primul rînd, efortul remarcabil de a crea un alfabet propriu pentru scrisul românesc prin elaborarea și apoi prin impunerea unor norme ortografice bazate pe alfabetul latinesc, alfabet menit să ofere românei o „haină” care să-i facă evidentă originea romanică, dar și să îi asigure unitatea în planul formei scrise, unitate imposibil de obținut prin utilizarea alfabetului chirilic, care menținea divizarea teritorială a scrisului literar. Prin aspectul fonetic promovat pentru limba română de cultură cu ajutorul alfabetului latinesc se urmărea deopotrivă normarea rostirii literare, pentru care unii învăţaţi cereau uneori evitarea vocalelor centrale și eliminarea unora dintre alternanțele consonantice, în încercarea de a păstra nemodificat radicalul unor cuvinte și de a pune în evidență și în acest mod structura lor morfologică. Prin înnoirea sistematică a lexicului literar, pentru a învinge „neajungerea” unei limbi ce trebuia să-şi asume statutul de instrument elevat de difuzare a culturii laice moderne, erau promovate, alături de numeroase neologisme latinești și romanice, „vorbele de rădăcină” ${ }^{\prime}$, lexeme moștenite, și derivatele pe baza acestora, create după tipare și cu afixe latinești.

Mai puțin importante pentru demonstrarea latinității limbii noastre, o serie de norme morfologice promovate de către cărturarii Școlii Ardelene vizau actualizarea, în perspectivă romanică, a unor forme specifice românei vechi (între acestea utilizarea infinitivului lung cu valoare verbală; v. Chivu, 2015, p. 183$190^{2}$ ), eliminarea unor omonimii flexionare (precum cea creată de identitatea formelor pentru persoanele 3 și 6 ale imperfectului; v. Gheție \& Teodorescu, 1965, p. 87-101; 1966, p. 175-183), acceptarea unor modele latino-romanice (clasele de adjective și de adverbe terminate în -e, v. Avram, 1992a, p. 234-250, respectiv formațiile participiale în -înd, -ind, v. Avram, 1992b, p. 205-217) sau impunerea unor forme verbale de tip cult (precum sum și sunt).

\footnotetext{
*Adresă de corespondență: gheorghe.chivu@gmail.com.

${ }^{1}$ Formularea apare în Iorgovici (1799/1979, p. 79 passim).

${ }^{2}$ Pentru exemple și bibliografie, vezi și Nedelcu (2013).
} 
Istoria ultimelor două forme verbale citate, grafii sau/și rostiri, pune în evidență un proces sinuos de elaborare a unor norme de tip cult în cadrul românei literare moderne, proces legat indisolubil de mișcarea latinistă ardeleană. Deloc linear, după cum vom încerca să arătăm în paginile următoare, acest proces a fost influenţat concomitent de două tendințe nu totdeauna convergente: utilizarea unor forme culte, preluate din latină sau modelate după tipare latinești, respectiv revitalizarea unor fenomene lingvistice cu circulație regională, manifestate în scrisul românesc literar de la sfîrșitul secolului al XVIII-lea pînă la începutul secolului al XX-lea.

II.1. Autorii Dicționarului tezaur al limbii române, singura lucrare destinată marelui public în care este consemnat sum, notează lapidar, fără nici o ilustrare, că „formele sum, sunt, suntem, sunteți s-au introdus în limba literară de școala latinistă” (DA 1934, p. 113, s.v. fi), formularea fiind reluată, cu redactare aproape identică, în Micul dicţionar academic (MDA 2002, p. 410, s.v. fi).

În citatul pe care l-am extras din Dicționarul Academiei, Sextil Pușcariu făcea, desigur, referire în primul rînd la principala gramatică ce ilustra latinismul academic (Cipariu, 1869/1987, 1876/1992), în care sum era recomandat ca formă de bază a „verbului substantiv” a $f i$ și în descrierea morfologică, și în exemplele ilustrative pentru sintaxă (Cipariu, 1869/1987, p. 274; 1876/1992, p. 19, 21, 71, 83, 206, 214). Sextil Pușcariu cunoștea însă cu certitudine atestările pe care forma în discuție le avea în scrierile anterioare ale învățatul blăjean (Cipariu, 1854; 1855; 1866).

Timotei Cipariu preluase și acceptase, în lucrările amintite, o formă întîlnită constant în scrieri ale latiniștilor ardeleni începînd de la sfirșitul secolului al XVIII-lea pînă în vremea sa ${ }^{3}$.

În 1794, sum (scris c8m) fusese notat de două ori într-un text beletristic, numit în mod curent Istoria amerii, inclus în Calendariul românesc tipărit cu litere chirilice la Viena ${ }^{4}$ : „eu sum numai o fată ignorantă”, „eu sum secură” (p. 33). Paul Iorgovici, considerat a fi alcătuitorul Calendariului și traducătorul Istoriei amerii (Ursu, 1963, p. 283-291; Chivu, 2002a, p. 90), consemnează forma și în Iorgovici (1799/1979), scriind-o tot cu litere chirilice: „sum, esci, este; sum, es, est; sein; sânt, ești, este” (p. 69).

Petru Maior (1819) utilizează și el forma sum, în coloana imprimată cu litere latine și ortografie etimologizantă din programaticul Dialog pentru începutul limbei română, tipărit la Buda ca anexă la Orthographia Romana sive Latino-Valachica și reluat nemodificat (chiar cu aceeași paginație) în Lexiconul românesclatinesc-unguresc-nemtesc din 1825: „sủm (sủnt) incredentiatu” (p. 54, 58) $)^{5}$. (În coloana imprimată cu litere chirilice, lui sủm în corespundea cłım.) În 1825, în textul propriu-zis al Lexiconului de la Buda, sủm este înregistrat ca echivalent al lui sint sub vocea escu: „Escu. Macedo-Valachice, sủm. V<ide> sủnt” (p. 206) ${ }^{6}$. Iar un an mai tîrziu, Ioan Alexi (1826) nota forma sủm înaintea lui sủnt în paradigma de indicativ prezent a verbului a fi: ,jo sủm, sủnt, ego sum vel escu" (p. 81).

Forma sum (ortografiată sủm, începînd cu anul 1819, în multe dintre scrierile alcătuite cu alfabet etimologizant), prezentă în lucrările lingvistice cu caracter programatic ale reprezentanților mișcării iluministe transilvănene ${ }^{7}$, pătrunsese și în alte texte tipărite dincolo de munți, dar și în unele dintre cărțile destinate școlii apărute în epocă la sud și la est de Carpați. În aceste din urmă surse, lui sum (respectiv sủm) prezent în cărțile imprimate cu litere latine și ortografie etimologizantă, i se alătură (mai rar, în gramatici

\footnotetext{
${ }^{3}$ În exemplele pe care le reproducem în paginile următoare, pasajele extrase din surse scrise cu litere chirilice sau cu alfabet de tranziție au fost transcrise interpretativ, în vreme ce fragmentele preluate din texte imprimate cu alfabet latin în manieră etimologizantă au fost reproduse ca atare, pentru a nu anticipa asupra rostirii formelor scrise sum, respectiv sunt.

${ }^{4}$ Vezi, pentru text, transcrierea publicată în Chivu (2002a, p. 91-98).

${ }^{5}$ Pentru ediția modernă a fragmentului citat, vezi Fugariu (1983, p. 608, 609) și Maior (1976, p. 303, 306).

${ }^{6}$ În articolul sủnt, a fi, fostu la care se face trimitere, sum este din nou prezent în redactarea primului sens al cuvîntului-titlu:

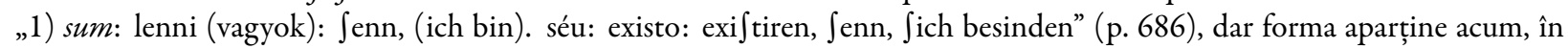
opinia noastră, limbii latine. (În reproducerea fragmentului anterior am respectat semnele ortografice și punctuația existente în Lexicon.)

${ }^{7}$ Utilizarea lui sum în Calendarul vienez din 1794 face doar în aparență excepție de la această constatare, întrucît, prin publicarea traducerii intitulate Istoria amerii, a fost urmărită deopotrivă promovarea unui nou tip de text beletristic și ilustrarea unei atitudini speciale față de forma unei scrieri literare. Vezi, pentru acestea, Chivu (2002b, p. 149-158).
} 


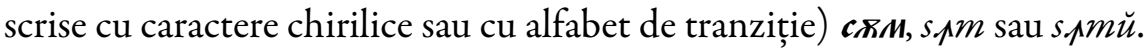

Astfel, Samuil Micu folosește forma sum în Cartea cătră cler și popor (Micu, 1824, p. 10). Ioan Alexi considera, în Alexi (1826), că sủm este formă de referință pentru flexiunea verbului a fi: „io sủm vel sủnt” (p. 77; vezi și p. 81). În același an, Nicolao Maniu Montan includea forma între exemplele ilustrative pentru limba română scrise cu litere latine în Maniu Montan (1826): „Eu sủm Domnul Dumned̦eul tủu” (p. 34), ,acum sủm cu o d̦i mai a própe de mórte” (p. 36). Seulescu îl plasa pe sîm (scris cxm) după sînt, în seria formelor de indicativ prezent 1 singular ale verbului a fi: „sânt și sâm, îs, escu” (Seulescu, 1833, p. 102). În 1848, Petru Maller Câmpeanu, autor ardelean stabilit la Iași ${ }^{8}$, îl includea pe sîm (scris, ca și la Seulescu, сxмM), recomandat ca primă formă: „eu sâm (sânt)” (Maller Câmpeanu, 1848, p. 93). În acelaşi an, Ioan Codru Drăgușanu, autodidactul transilvănean devenit, pentru un timp, profesor la Ploiești, constata, în Rudimentele gramaticei române, manual destinat începătorilor, comentînd „studiele limbistice” ale unui enigmatic filolog latinist, Ğ.M.F. (?), că forma sîm (ortografiată s.pmŭ) face parte din paradigma „clasică” a verbului a fi (Codru, 1848, p. 69). Nicolau Bălășescu, originar din sudul Transilvaniei, cunoscut ca mitropolitul Nifon, scria, în Gramatica română tipărită, tot în 1848 , la Sibiu, în primul rînd pentru seminariști: „românii în vorbire întrebuințează des îsủ și sủ (sum), în loc de sânt; ba am auzit esc, esci, este, estem, esteți, estû" (Bălășescu, 1848, p. 105) ${ }^{9}$, iar doi ani mai tîrziu îl recomanda și el pe sîm (scris cxm) în Elemente de Grammatică română pentru școlarii începători, manual apărut de această dată la București: „eu sâm (escŭ, îsu)" (p. 56; vezi și p. 74, 76). Iar, în 1860, Gavrile Munteanu îl cita pe sum, alături de sunt, sủ și escủ (Munteanu, 1860, p. 48), în Partea etimologică (adică morfologică) a unei Gramatici române redactate „pentru clasile gimnasiali inferiori”, tipărită la Braşov.

Forma sum, notată în astfel de texte datorate latiniştilor ardeleni, respectiv unor autori transilvăneni sau moldoveni influențați de concepția lingvistică a celor dintîi, a avut un ecou limitat în textele românești din a doua jumătate a secolului al XIX-lea.

Timotei Cipariu, care o recomanda în prima Gramatecă academică a limbei române (București, 1869), a evitat-o în scrierile sale nonlingvistice ${ }^{10}$, iar A.T. Laurian și I.C. Massim nu au selectat-o, ca formă recomandabilă (s.v. fire), în Dicționarul limbei române, proiectul primului dicționar academic, tipărit între 1871 și 1877 (Laurian \& Massim, 1871).

Învăţaţii latiniști şi adepții lor (în primul rînd juriștii, funcționarii publici și jurnaliștii) ${ }^{11}$ au apelat totuşi la sum (posibil chiar în conversaţii de tip academic), întrucît B.P. Hasdeu, adversar convins al latinismului, utilizează frecvent forma, aparent cu intenție stilistică, în Duduca Mamuca (și în varianta acesteia Micuța), respectiv în Orthonerozia sau Trei crai de la răsărit ${ }^{12}$. Șarjînd, se pare, o anumită manieră de exprimare $^{13}$, învăţatul filolog plasează forma în vorbirea personajului principal al nuvelei, student în drept, și în aceea a lui Vladimir Aleșchin-Uho, jurnalist: „sum prea rumen la față” (p. 154, 227), „Nu sum în stare! Nu sum frumos!" (p. 197) ${ }^{14}$. Iar în piesa de teatru numită Orthonerozia, sum este utilizat, cu aceeași funcție de caracterizare prin limbă a personajului, în scrisoarea pe care Numa Consule, personajul prin care este șarjat latinismul, i-o trimite lui Hagi-Pană: „eu nu sum emptore, io sum procu” (Hasdeu, 2003, p. 223),

\footnotetext{
${ }^{8}$ Petru Maller tipărise la Buda, în 1832, o Grammatică hungarico-valachică, destinată şcolii (Maller, 1832).

${ }^{9} \hat{I}$ fragmentul citat, scris ca întreaga carte cu litere chirilice, singur sum este imprimat cu litere latine. Nu este exclus, de aceea, ca autorul să indice aici nu o formă flexionară românească, ci un echivalent (sau un etimon?) latinesc pentru (i) sủ.

${ }^{10}$ Forma sum, evitată în Jurnal (scris, este drept, în 1836), în Scrisorile din Italia (datate 1852) și în Memorii (redactate în 1855) (Cipariu, 1972), apare o singură dată într-un discurs, pregătit în 1863 pentru Dieta de la Sibiu: „io nu sum atât de comunist..." (Cipariu, 1984, p. 141).

${ }^{11}$ Cercetarea textelor juridice și administrative, respectiv a publicațiilor periodice apărute în a doua jumătate a secolului al XIX-lea va scoate, foarte probabil, la lumină informații suplimentare asupra utilizării formei verbale sum, știut fiind că cele două domenii ale culturii scrise (justiția și administrația) s-au aflat sub o puternică influență latinistă.

${ }^{12}$ Referirile la cele două texte sînt făcute prin intermediul edițiilor alcătuite de Ion Șeulean (Hasdeu, 1973), respectiv de Stancu Ilin și I. Oprișan (Hasdeu, 2003).

${ }^{13}$ În Duduca Mamuca, Hasdeu (1973) introduce chiar o referire directă la Timotei Cipariu, într-un pasaj atribuit eroului principal, Toderiță N.N.: „Voiești oare, cetitoriule, ca să te iubească sexul sau, cum zice d-l Cipar, sepsul frumos?” (p. 127).

${ }^{14}$ A se vedea, pentru alte atestări ale lui sum, p. 155, 156, 157, 162, 184, 185, 188, 191, 195, 197, 199, 208, 211, 215, 216, 230.
} 
„Io, Peregrine Pannonie, sum antica classicitate, Roma avitica” (p. 243).

Ardelenii mai puțin instruiți vor fi folosit și ei forma sum, evident sub influența şcolii și datorită prestigiului avut în zonă de mișcarea latinistă, de vreme ce Teofil Frâncu și George Candrea au consemnato, în 1888, în vorbirea moților de pe valea Hălmagiului („Verbul $a f i$ se aude în următoarele forme: $\hat{\imath}$ s, sum, sâmt, sânt, escŭ, estŭ; aceste două din urmă se aud în comuna T,ebea, iar sum se aude pe valea Hălmagiului, pe cînd mi-'s se aude numai în părțile inferioare ale Zărandului”, Frâncu \& Candrea, 1888, p. 78), iar V.E. Ardelean a introdus-o în textul poeziei intitulate Marşul redactorilor „Tribunii”, scrisă în 1903, imediat ce cunoscuta revistă sibiană și-a încetat apariția: „sum agitator” ${ }^{15}$.

II.2. Datele prezentate în paginile anterioare confirmă valabilitatea constatării formulate, în 1934, de către Sextil Pușcariu: sum a fost o normă morfologică de tip savant, introdusă în româna literară de către reprezentanții mișcării latiniste, la sfîrşitul secolului al XVIII-lea. (Această normă nu trebuie confundată cu sum, folosit rar, tot de latiniști ${ }^{16}$, în deceniile de mijloc ale secolului al XIX-lea, ca urmare a "reabilitării” și scrierii etimologizante a lui sem, rostit acum săm, vechea formă de indicativ prezent persoana 1 plural a aceluiași verb a fi.)

Consemnat pentru prima dată în texte imprimate cu alfabet chirilic, în cadrul cărora principiul fonologic era dominant ${ }^{17}$, sum (scris $\mathbf{c} 8 \mathbf{m}$ ) corespundea, desigur, în jurul anului 1800, unei norme ortoepice reale, identice în mod firesc cu rostirea formei gramaticale latinești din care provenea ${ }^{18}$. Incepînd cu anul 1819 și pînă la abandonarea etimologismului ca principiu ortografic dominant în scrierea românească cu litere latine, sum, cu varianta grafică sủm, a corespuns însă ortoepic lui sîm. (Utilizatorii grafiei sum/sủm, cunoscînd, desigur, forma ç一m, propusă de Paul Iorgovici, au interpretat-o, foarte probabil, în spiritul scrisului etimologizant.) Indică pentru prima dată această rostire grafia c čm $\mathbf{m}$, existentă în coloana cu litere chirilice din Dialogul pentru începutul limbei română (p. 54, 58), și o confirmă atît modul de notare a formei în gramaticile imprimate cu litere chirilice sau cu alfabet de tranziție, în prima jumătate a secolului al XIX-lea, în Moldova și Țara Românească ( $\mathbf{c m}$ M, s.^m sau s.pmŭ), cît și o formulare explicită datorată lui Timotei Cipariu: „în sum, u se pronunță oscur, ca x” (Cipariu, 1854, p. 148; 1876/1992; 1869/1987, p. 46). Sub influența grafiei, influență aproape normală în cultura românească, în care scrisul chirilic, scris de tip fonologic, avusese o tradiție îndelungată, rostirea sum, atestată de textele lui Iorgovici, reapare, după 1860 , atît în vorbirea unor intelectuali mai mult sau mai puțin apropiați de latinism ${ }^{19}$, cît și, dacă informațiile furnizate de Teofil Frâncu și George Candrea sînt exacte ${ }^{20}$, în vorbirea locuitorilor din sate de pe valea Hălmagiului.

Avînd deci, mai mult de un secol, o istorie și o evoluție sinuoase (rostire și/sau grafie), sum, normă cultă cu ecou limitat chiar în lucrările cu caracter lingvistic ale latiniștilor, dispare practic din limba literară la începutul secolului al XX-lea.

Alternanța dintre sum și sîm în textele transilvănene și prezența exclusivă a lui sîm în gramaticile tipărite în Moldova și în Țara Româneascăă ${ }^{21}$ pun în evidență, dincolo de diferențele existente între scrisul

\footnotetext{
${ }^{15}$ Informația ne-a fost comunicată de Gavril Scridon, iar textul integral al poeziei urma să apară în cadul notelor ce însoțeau o ediție a operei lui G. Coșbuc proiectată să apară după 1990, la Chişinău.

${ }^{16}$ A se vedea, spre exemplu, atestarea existentă în 1842, în Laurian (2002, p. 164), și aceea din Cipariu (1972, p. 133).

${ }^{17}$ Vezi, pentru abaterile de la acest principiu, Chivu (2000b, p. 100-105).

${ }^{18}$ Vezi Chivu (2000a, p. 434-435). Forma sum era utilizată, de altfel, de Paul Iorgovici exclusiv pentru persoana 1 singular a indicativului prezent.

${ }^{19}$ Atestările formei sum extrase din Duduca Mamuca (și Micuţa), respectiv din Orthonerozia pot fi, în ciuda intenției ironice a autorului, un argument în favoarea acestei afirmații. Vezi și Cipariu (1869/1987, p. 275): „Persoana 1 sing., deși se pronunță în două moduri [sum, - su], e tot numai o formă sum, lat. sum, cu diferență că aici - $m$ finale latin se pronunță au nu se pronunță. ... Sum însă astăzi se aude mai rar și cu $x$ în loc de $u$....

${ }^{20} \mathrm{H}$. Tiktin se îndoiește de veridicitatea informației privitoare la prezența lui sum în vorbirea oamenilor simpli, de vreme ce alătură formei extrase din monografia alcătuită de Teofil Frâncu și George Candrea un semn de întrebare. Vezi Tiktin (1906, p. 624, s.v. $f$ ).

${ }^{21}$ Textele lingvistice publicate în această ultimă provincie, în care este notat sîm, sînt alcătuite de către autori originari din
} 
etimologizant și cel cu litere chirilice, respectiv de o posibilă evoluție internă (sum, împrumut morfologic din latină, a putut fi rostit sîm, în lucrările datorate latiniștilor, prin „românizare” fonetică $\breve{a n}^{22}$ ), existența, în epoca de început a românei literare moderne, a unei încercări de revitalizare a unor forme considerate „clasice", mai apropiate de latină ${ }^{23}$, notate în textele vechi și înregistrate în variantele dialectale conservatoare ale dacoromânei.

Învățații Școlii Ardelene îl cunoșteau desigur pe sîm, forma de indicativ prezent persoana 1 singular, din graiul bănățean ${ }^{24}$, din unele graiuri transilvănene și din dialectul aromân ${ }^{25}$. Timotei Cipariu constata și el că forma ,încă tot se mai aude în gura poporului din Transilvania pe alocurea” (Cipariu, 1866, p. 141 $)^{26}$. Iar Gh. Săulescu, dacă nu acceptase, cumva, în Gramatica din 1833, o normă ardelenească sub influența lui Petru Maller Câmpeanu, întîlnise, foarte probabil, aceeași formă în texte vechi alcătuite în colțul nord-estic al țăriii ${ }^{27}$.

Deși reprezenta, la nivelul limbii române, rezultatul unei evoluții fonetice diferite ( $\operatorname{sim}$ din unele graiuri dacoromânești și din aromână apăruse sub influență sud-slavă ${ }^{28}$, în vreme ce forma omonimă existentă în graiurile nordice și în vechile noastre texte era o variantă fonetică a lui sîmt < sînt), forma sîm pentru indicativ prezent 1 singular a fost considerată, foarte probabil, atît de Petru Maior, cît și de Gh. Seulescu, continuatoare a formei latinești sum. Timotei Cipariu nota, de altfel, în Elemente de limbă după dialecte și monumente vechi, că sîm este formă „originarie” (p. 148) ${ }^{29}$, după ce alți învățaţi latiniști, precum Ioan Codru Drăgușanu, o consideraseră „,formă clasică” (p. 69). (Sum, prezent ca formă cultă în limba română, a fost înregistrat, în spaţiul sudic al Romaniei, în Calabria, fiind considerat o continuare firească a formei gramaticale latinești corespunzătoare; v. Rohlfs (1968, p. 540).)

III.1. Forma sunt a fost considerată, ca și sum, o normă cultă, „introdusă în limba literară de școala latinistă” (DA 1934, p. 113, s.v. fi), iar atestările consemnate în texte susțin această afirmație.

Primele consemnări ale lui sunt, utilizat inițial doar pentru persoana 3 plural indicativ prezent a verbului a fi, trimit, ca și în cazul lui sum, spre cele două tipărituri de la sfîrşitul secolului al XVIII-lea datorate (sau doar atribuite) lui Paul Iorgovici. În Calendariul vienez din 1794, în textul traducerii numite în mod curent Istoria amerii, apar forma „clasică” sunt (scrisă c४ $\mathbf{N T}$ ): „mijlociri sunt de a repara” (p. 30) și forma analogică sunteți (scrisă cชнтеци): „de vină sunteți voi”, „voi sunteți un moștean bogat” (p. 28), „,voi sunteți un om onest” (p. 30), „,oi sunteți nește oameni” (p. 32), „sunteți a nu ve putea întoarce” (p. 33). Iar în Observații de limba rumânescă, tipărite la Buda, în 1799, numărul atestărilor pentru sunt și suntem crește

\footnotetext{
Transilvania.

${ }^{22}$ Vezi, pentru această ipoteză, Chivu (2000a, p. 434-435), p. 434-435.

${ }^{23}$ Pentru acest subiect, vezi detalii la Gheție (1967, p. 221-223).

${ }^{24}$ Petru Maior nu va fi avut știință de consemnarea lui sîm în Anonymus Caransebesiensis (vezi Chivu, 2008, p. 117), întrucît textul a fost descoperit de B.P. Hasdeu, la Budapesta, abia în anul 1871, iar primele extrase din el (fără ca acestea să conțină și intrarea sẻm - sum) au fost tipărite în 1891 (vezi Hasdeu, 1891, p. 1-48). Cf. Ivănescu (1980, p. 628), unde se afirmă că sum utilizat de Petru Maior era o particularitate dialectală bănățeană. (Savantul ieșean a reluat aici o idee formulată prima dată în Ivănescu (1944, p. 131-132).)

${ }^{25}$ Vezi, pentru aceasta, consemnarea făcută în Lexiconul de la Buda, s.v. escu, reprodusă anterior, prin care sum este considerat "macedo-valachice”.

${ }^{26}$ Forma sîm, provenită din sîmt în fonetică sintactică, a fost consemnată însă, ca formă de persoana a 3-a plural, în zona centrală a Transilvaniei, în timpul anchetelor pentru ALR 1972: h. 2157).

${ }^{27}$ Dicționarul limbii române consemnează existența unor variante sîn, sîm (DA 1934, p. 113, s.v. fi), desigur, în urma cercetării textelor vechi sau a cunoașterii vorbirii locale.

${ }^{28}$ Potrivit cercetărilor de dialectologie modernă, sîm, preluat din sîrbă sau din bulgară, este prezent atît în meglenoromână (vezi Atanasov, 1984, p. 528 și 2002, p. 250), cît și în istroromână (Sîrbu \& Frățilă, 1998, p. 271; Kovačec, 1998, p. 78). Forma a fost înregistrată, cu puține atestări, și în dacoromână, în Banat (ca influență sîrbească), în Muntenia și în Dobrogea (ca influență bulgărească). Vezi ALR 1972, h. 2156.

${ }^{29}$ August Scriban considera și el că sîm este descendent direct al unei forme latinești, întrucît, în Scriban (1939), s.v. sînt, fost, a fi, notează: „lat. sìm, sìmus, sìnt [cl. sum, sŭmus, sunt] de unde s-au făcut sîm [azi sînt], sem [apoi sîntem, azi sîntém], set [apoi sînteți, azi sîntéți], sînt". Vezi, pentru aceeași opinie, Fugariu (1983, p. 608, nota b).
} 
semnificativ: „Mai toate de cătră frig sunt îmbrăcate cu vesminte” (p. 1), „sunt noauo bune au ba” (p. 3), ,în limba noastră sunt fundate” (p. 14), „Cu aceste particule sunt împreunate cuvintele” (p. 15), ,Vorbele sunt semnele preceptului minții” (p. 21), „cuvintele sunt semnele arbitrarie” (p. 21); vezi pentru sunt și p. 18, 23, 24, 25, 26, 29, 30, 34, 37, 73, 74, 77, 79, 80, 81, 82, 88, 89, 90, 92; „Suntem siluiți a da unui nome mai multe înțelesuri” (p. 22), „Noi suntem auzitorii legiei” (p. 90). Forma sînt, specifică nu doar vechiului scris românesc, ci și scrierilor chirilice alcătuite în epocă, apare în Observații doar în patru contexte, foarte probabil ca urmare a unor „scăpări” ale tipografului sub presiunea normei uzuale în scrisul vremii: „Cele mute sînt și mai tare la trup” (p. 1), „Aceste toate la toți sînt cunoscute” (p. 8), ,acum sînt cu sîrbii” (p. 13), „sum, esci, este; sum, es, est; sein; sînt, ești, este” (p. 69).

Forma verbală propusă de Paul Iorgovici este înregistrată, sub grafia sûnt, de Gheorghie Constantin Roja, în Măiestria ghiovăsirii românești cu litere latinești, apărută la Buda, în 1809 (p. 43). Este consemnată, ca formă de indicativ prezent 3 plural, și în Cântare despre începutul și starea de astăzi a românilor, tipărită cu litere latine, tot la Buda, sub semnătura lui I. Theodorovici Nica, în 1813 (p. 1, 5). Este notată, cu aceeaşi valoare morfologică și cu aceeași formă grafică (sûnt), la Vasile Gergely de Csokotis, în Omu de lume, Viena, 1819 (p. VII, 1, 8, 70).

Forma sunt (scrisă și sủnt) este utilizată, în 1819, de Petru Maior, în coloana imprimată cu alfabet etimologizant din Dialog pentru începutul limbei română, anexa la Orthographia Romana sive LatinoValachica, dar în acest text corespunde deopotrivă indicativului prezent 3 plural și 1 singular al verbului $a$ $f:$ : „precum si în scripturile lor se vede, nu escu (sủnt) fỏrả indoelả” (p. 54), „doả sunt pareri le invetiaţilor” (p. 55), „multe cuvènte ... nu sunt in limba latinả” (p. 56), „limbile aqueste sunt cuscrite la olaltả, érỏ de limba latinả ... sunt strảinate" (p. 57) ${ }^{30}$.

Formelor sunt și sủnt, menținute la republicarea Dialogului lui Petru Maior ca parte introductivă pentru Lexiconul românesc-latinesc-unguresc-nemțesc din 1825, li se alătură, în corpul dicționarului budan, mai multe atestări: „sủnt, șed̦u” (p. 2) ${ }^{31}$, „Escu. Macedo-Valachice, sum. V. sünt” (p. 206), „sủntu, a fi, fostu”, ,sủntu de faciê”, ,sủntu depảrtatu”, „sủntu ỉn lỏuntru”, ,sủntu ỉntrả quariiva”, ,sủntu preste quineva” (toate pe p. 686), ,nu sủntu” (p. 687). În pasajele scrise cu litere chirilice din ultimele două scrieri amintite, Dialogul și Lexiconul, lui sunt, respectiv sủnt îi corespund fără excepție grafii cu ius (скхNт) sau cu ier mare $(\mathbf{c} \mathbf{k} \mathbf{T})^{32}$.

Forma sunt, scrisă de această dată doar fără semn diacritic, este consemnată și în Dicționariul românesc, latinesc și unguresc, tipărit sub oblăduirea lui Ioan Bobb (tom II, Cluj, 1823, p. 428-429). Samuil Micu folosește și el forme cu $u$ fără semn diacritic în Cartea cătră cler și popor (Oradea, 1824; sunt, p. 9, 12; vezi și suntem, p. 14, sunteți, p. 6, 7). Nicolao Maniu Montan (1826) notează sŭnt (3 pl., p. 25, 26, 41), sunt (p. 41) și sŭntem (p. 42). Ioan Alexi îl consemnează pe sủnt ca formă pentru persoanele 1 singular și 3 plural, în Alexi (1826): ,jo sủm vel sủnt” (p. 77), ,jo sủm, sủnt, ego sum ..., ei sủnt, illi sunt, elle sủnt, illæ sunt" (p. 81). Iar Timotei Cipariu utilizează forma suntu (3 pl.) în Ecloga ce apărea în 1833, la Blaj (p. 4).

În Muntenia, Ion Heliade Rădulescu, după ce editează, în 1839, în Curier de ambe sexe, Observațiile de limbă rumânească ale lui Paul Iorgovici ${ }^{33}$, acceptă și el, desigur sub influența învățatului bănățean ${ }^{34}$, în locul lui sînt (scris cхnтళ sau cmnt) forma sunt (3 pl., scrisă în periodurile II, III și IV ale Curierului, tipărite cu alfabet de tranziție, cśnt; II, p. 84, 86, 91, 351, 352, 358, 375; III, p. 169, 190; IV, 31, 33). În periodul V și apoi în periodul VI ale Curierului de ambe sexe, cînd alfabetul de tranziție lasă locul celui latinesc, forma, trimițînd în continuare la indicativul prezent 3 plural, este scrisă sunt (V, p. 2, 31, 83, 245;

\footnotetext{
${ }^{30}$ Trimiterile se fac la paginile textului republicat la începutul Lexiconului de la Buda. Vezi și ediția modernă a Dialogului, realizată de Florea Fugariu (în Maior, 1976).

${ }^{31}$ Forma sủnt era prezentă în același context și în prospectul dicționarului lui Samuil Micu, tipărit la Buda, în anul 1814.

${ }^{32}$ Vezi și Chivu (2000a, p. 431-437).

${ }^{33}$ Ediția publicată în 1939, cu alfabet de tranziție, în Curier de ambe sexe, periodul II, nr. 6, p. 82-118, a fost tipărită și în Curierul românesc din același an (nr. 55, 56, 61, 65, 67, 72).

${ }^{34}$ Gh. Ivănescu considera și el (Ivănescu, 1980, p. 665) că Ion Heliade Rădulescu a scris sunt și suntem sub influența lui Paul Iorgovici.
} 
VI, p. 85, 90).

După 1860, grafia sunt este recomandată deopotrivă de Gramateca limbei române (București, 1869) scrisă de Timotei Cipariu: „suntu, -su” (I, p. 274) și de Dicționariul limbei române al lui August Treboniu Laurian și Ioan C. Massim: „indic. presente: ... su sau sunt sau suntu; in urmarea acestei forme d'in pers. III pl. s'au formatu dupo analogi'a verbeloru de conjugationea III ... suntu, suntemu, sunteti” (I, p. 1240), ambele lucrări normative tipărite sub egida Academiei, dar și de Regulele ortografice ale limbei române, adoptate de Ministeriul Instrucțiunii Publice și al Cultelor (București, 1871): „sûntŭ” (p. 5).

Textele literare din a doua jumătate a secolului al XIX-lea vor accepta treptat norma ortografică academică, sunt continuînd să fie însă normă ortografică explicită și la începutul secolului al XX-lea ${ }^{35}$.

III.2. Ca și sum (scris în primele sale atestări c $8 \mathbf{M}$ ), forma verbală sunt (scrisă iniţial c $8 \mathbf{N T}$ ) a fost deci introdusă în scrisul românesc de către Paul Iorgovici, prin Calendariul rumânesc din 1794 și prin Observații de limba rumânească, din 1799, ambele forme ilustrînd, foarte probabil, date fiind regulile scrisului chirilic, dar și valoarea morfologică specifică, rostiri modelate după formele verbale latinești pe care le reproduceau.

După 1800, sunt, scris de această dată cu litere latine în diverse maniere ortografice (sunt, sûnt, sủnt, sŭnt), este consemnat constant în scrierile iluminiștilor ardeleni și bănățeni. Iar după 1840, forma a fost acceptată, sub influența latiniștilor, și în scrieri elaborate și imprimate dincoace de munți, devenind, în a doua jumătate a veacului al XIX-lea, după generalizarea scrisului cu litere latine, normă ortografică oficială.

Coexistînd cu sent și sint (literele vocalice din aceste forme erau însoțite adesea de semne diacritice: sẻnt, sênt, sênt; sint, sînt, sinnt), prezente în numeroase texte contemporane scrise sau imprimate cu litere latine (între acestea două lucrări normative importante, Elementa lingux Daco-Romana sive Valachice, Viena, 1780; ediția a II-a, Buda, 1805, respectiv Lexiconul rumânesc, latinesc, unguresc, nemțesc, Buda, 1825), și avînd drept corespondent în grafia chirilică, uneori chiar în scrieri datorate acelorași autori, forme

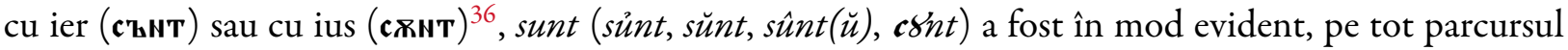
secolului al XIX-lea, grafie etimologizantă, în care $u(\hat{u}, \breve{u}$ sau $\hat{u})$ nota o vocală centrală.

Constată explicit existența acestei rostiri Ion Heliade Rădulescu, în notaţiile lămuritoare asupra alfabetului latin adoptat în periodul $\mathrm{V}$ al Curierului de ambe sexe: „Mai vedem iară că $(u)$ și $(i)$ adesea, înaintea consoanelor nasale $(m)$ și $(n)$, se pronunță pe nas, ca $(8)$ slavon, precum ... sunt ca sânt" (p. VIII). Timotei Cipariu făcea de asemenea precizarea, în Principie de limbă şi de scriptură din 1866, că sunt din scrisul cu litere latine se pronunță „cu $u$ oscur ca $\boldsymbol{x}$ (p. 148-149). Iar autorii Regulelor ortografice ale limbei române, adoptate de Ministeriul Instrucțiunii Publice și al Cultelor din 1871 notau și ei că ,accentul circumflex $(\wedge)$ pus deasupra vocalelor plenisune [în forme de tipul sûntŭ] arată că aceste vocale trebuie a se pronunța atunci cu un ton nasal, echivalinte vocalei cirilice $x "$ (p. 5).

Devenită treptat, în deceniile de început ale secolului al XX-lea, rostire literară sub influența grafiei, sunt a continuat să alterneze mult timp cu forma etimologică, sînt ${ }^{37}$.

Înregistrată pentru prima dată la sfîrșitul secolului al XVIII-lea, în două texte datorate bănățeanului Paul Iorgovici, forma sunt (scrisă c $8 \mathbf{N T}$ ), coexistînd cu sum (scris c8m) și avînd exact valoarea morfologică din limba latină ${ }^{38}$, pare indisolubil legată de modelul latinesc promovat de reprezentanții Școlii Ardelene. La cumpăna secolelor al XVIII-lea și al XIX-lea, suntu (scris inițial cu litere grecești, apoi în 1813, la Mihail Boiagi, cu litere latinești) apare însă în mai multe scrieri aromânești, apărute la Viena, la Veneția sau la Buda (Boerescu, 2002, p. 136-137). Consemnează forma verbală suntu, specifică aromânei (Papahagi, 1963, p. 659-660, s.v. hiu), Constantin Ucuta, în Nea paidagogia, abecedar din 1797 ( $\sigma 8 v \tau$, , p. II, 7, 40),

\footnotetext{
${ }^{35}$ Vezi Regule ortografice, Glosar, Institutul de arte grafice „Carol Göbl”, București, 1904, p. 14.

${ }^{36}$ A se vedea exemplele culese cu litere latine, reluate, explicativ, cu grafie chirilică în ortografiile vremii, dar mai ales textele culese pe coloane paralele, cu alfabet etimologizant și cu grafie chirilică, din Dialogul pentru începutul limbei română al lui Petru Maior, respectiv din introducerea Lexiconului de la Buda.

${ }^{37}$ În Pușcariu \& Naum (1941, p. 69), se face constatarea că „în rostirea obișnuită se aud forme cu â în loc de $u$, deci sânt, sântem, sânteți, sânt".

${ }^{38}$ Forma sum corespundea persoanei 1 singular indicativ prezent, iar sunt persoanei 3 plural.
} 
Daniil Moscopoleanu, în Eisagogiki didaskalia (= Invățătură introducătoare), din 1802 (p. 3), şi Mihail Boiagi, în Grammatiki romaniki itoi Makedovlabiki, din 1813 (p. 68, 132, 136, 226).

Va fi preluat Paul Iorgovici forma sunt din limba latină? Va fi acceptat o particularitate a vorbirii românilor sud-dunăreni, pe care o cunoștea din contactele avute cu reprezentanții comunităţilor aromânești din Buda și din Viena, în încercarea de a crea o normă literară prin punerea la contribuție a unor fapte lingvistice cunoscute din variante istorice ale românei? (Petru Maior opina în 1819, în Orthographia Romana că limba literară pe care doreau să o creeze latiniștii ardeleni „trebuie să fie potrivită cu natura limbii române și să cuprindă toate dialectele acestei limbi”, p. IV.) Sau îl va fi descoperit pe sunt într-unul din graiurile locale vorbite în zona Banatului ? ${ }^{39}$

Oricare dintre răspunsurile sugerate mai sus are șansa de a fi adevărat. Corelînd informațiile de care dispunem, considerăm însă că, exact ca în cazul lui sum, latiniștii ardeleni vor fi crezut că sunt, propus de Paul Iorgovici după model latinesc, este foarte probabil o formă „clasică”, păstrată din latină în aromână, respectiv în graiuri dacoromânești cu caracter conservator (deși forma dialectală în discuție, $\operatorname{sunt}(u)$, corespunde în realitate nu formei latinești sunt, ci unei transformări fonetice accidentale—transformarea lui $\hat{\imath}$ din sîntu în $u$ prin asimilare vocalică regresivă).

IV. Analiza întreprinsă în paginile anterioare argumentează ideea că sum și sunt, forme verbale culte, apărute în scrisul literar românesc în același timp, în texte de la sfîrșitul secolului al XVIII-lea datorate lui Paul Iorgovici, au avut o istorie şi o evoluție similare.

Propuse inițial ca rostiri literare modelate după limba latină, cele două forme verbale au fost acceptate, dar și reinterpretate de majoritatea învăţaţilor ardeleni, impunîndu-se rapid în scrisul cu litere latine ca grafii etimologizante, înainte de a redeveni, de data aceasta sub influența grafiei cu litere latine (în condițiile tradiției fonologice a scrisului românesc), norme de rostire literară.

Istoria celor două forme verbale culte este similară și în ceea ce privește punerea lor în relație cu rostiri dialectale ce au putut părea conservatoare, sîm, respectiv suntu, pe care latiniștii ardeleni le-au considerat (în mod eronat) reminiscențe ale unor forme moștenite din limba latină.

\section{Bibliografie}

\section{A. Izvoare}

*** Lexicon românesc, latinesc, unguresc, nemțesc, Buda, 1825.

*** Regule ortografice, Institutul de arte grafice „Carol Göbl”, București, 1904.

*** Regulele ortografice ale limbei române, adoptate de Ministeriul Instrucțiunii Publice și al Cultelor, București, Imprimeria Statului, 1871.

Alexi, I. (1826). Gramatica Daco-Romana sive Valachica, Viennæ.

Bălășescu, N. (1848). Gramatică română pentru seminarii și clase mai înalte (Grammatica Daco-Romana), Sibiu.

Bobb, I. (1823). Dicționariul românesc-latinesc și unguresc, II, Cluj.

Chivu, Gh. (ed.) (2008). Dictionarium Valachico-Latinum, primul dicționar al limbii române, Editura Academiei Române, București.

Cipariu, T. (1850). Elemente de Grammatică română pentru școlarii începători, București.

Cipariu, T. (1854). Elemente de limba română după dialecte şi monumente vechi, Blaj.

Cipariu, T. (1855). Compendiu de Gramateca limbei române, Sibiu.

Cipariu, T. (1866). Principie de limbă și de scriptură, Blaj.

Cipariu, T. (1869/1987, 1876/1992). Gramateca limbei române, Partea I. Analitica, Partea a II-a. Sintetica, București, vol. I, II (ed. modernă de Carmen Pamfil, în T. Cipariu, Opere, I-II, Editura Academiei Române, București)

Cipariu, T. (1972). Jurnal, ediție Maria Protase, Editura Dacia, Cluj-Napoca.

Cipariu, T. (1984). Discursuri, ediție Ștefan Manciulea, Ion Buzași, Editura Dacia, Cluj-Napoca.

\footnotetext{
${ }^{39}$ Unul dintre autorii Tratatului de dialectologie românească (Neagoe, 1984, p. 262) îl consemnează pe sunt în Banat, dar forma a fost înregistrată și în graiuri din sudul și din centrul Transilvaniei (vezi Zdrenghea, 1948, p. 195-197; ALR 1972, hărțile 2156, 2157, 2158). Facem abstracție de înregistrarea formei sunt în puncte izolate din Muntenia, Dobrogea, centrul Moldovei, care, chiar dacă ar fi vechi (fapt puțin probabil), nu ar fi fost cunoscute lui Paul Iorgovici.
} 
Codru I.G. (1848). Rudimentele gramaticei române, București.

Frâncu, T. \& Candrea, G. (1888). Românii din Munții Apuseni (Moții), București.

Fugariu, F. (ed.) (1983). Școala Ardeleană, II, Editura Minerva, București.

Hasdeu, B.P. (1891). Anonymus Lugoshiensis. Cel mai vechi dicționar al limbei române, după manuscriptul din Biblioteca Universității din Pesta, în „Revista pentru istorie, archeologie și filologie”, nr. VI, p. 1-48.

Hasdeu, B.P. (1973). Duduca Mamuca. Din memoriile unui studinte, ediție Ion Șeulean, Editura Dacia, Cluj-Napoca.

Hasdeu, B.P. (2003). Opere, IV. Dramaturgia, ediție Stancu Ilin, I. Oprișan, București.

Heliade Rădulescu, I. (1828/1980). Gramatică românească, Sibiu; ediție Valeria Guțu Romalo, Editura Eminescu, București.

Iorgovici, P. (1799/1979). Observații de limba rumânească, Buda; ediție Doina Bogdan-Dascălu, Crișu Dascălu, Editura Facla, Timişoara.

Laurian, A.T. (2002). Tentamen criticum, ediție Katalin Dumitrașcu, Editura Universitaria, Craiova.

Laurian, A.T., Massim, I.C. (1871). Diç̦ionarul limbei române, [I], București.

Maior, P. (1819). Orthographia Romana sive Latino-Valachica, Buda.

Maior, P. (1976). Scrieri, II, ediție Florea Fugariu, Editura Minerva, București.

Maller, P. (1832). Grammatica Hungarico-Valachica, Buda.

Maller Câmpeanu, P. (1848). Grammatică românească, Iași.

Maniu Montan, N. (1826). Orthoepia Latina, Latino-Valachica, Hungarica, Germanica et Serbo-Valachica, Cibinii.

Micu, S. (1824). Cartea cătră cler și popor, Oradea.

Micu, S. \& Șincai, Gh. (1780, 1805/1980). Elementa lingux Daco-Romana sive Valachicae, Viena, Buda; ediție Mircea Zdrenghea, Editura Dacia, Cluj-Napoca.

Munteanu, G. (1860). Gramatica română pentru clasile gimnasiali inferiori, [I]. Partea etimologică, Braşov.

Seulescu, G. (1833). Grammatică românească, Iași.

\section{B. Lucrări de referință}

ALR 1972 = Atlasul lingvistic român, Serie nouă, VII. Verbul, [București], 1972.

Atanasov, P. (1984). Meglenoromâna, în Tratat de dialectologie românească, Scrisul Românesc, Craiova, p. 476-550.

Atanasov, P. (2002). Meglenoromâna astăzi, [București].

Avram, M. (1992a). Cultisme adverbiale cu sufixul - $\boldsymbol{e}$ in limba română, în Studii de morfologie a limbii române, Editura Academiei Române, București, 2005, p. 234-250.

Avram, M. (1992b). Din istoria formațiilor participiale moderne in -ând, -ind, în Studii de morfologie a limbii române, Editura Academiei Române, București, 2005, p. 205-217.

Boerescu, P. (2002). Din istoria formelor grafice sunt, sint, sent și a variantelor acestora cu semne diacritice, în „Limba română”, vol. LI, nr. 4-6, p. 133-141.

Chivu, Gh. (2000a). Este sunt o simplă grafie latinizantă?, în „Limba română”, vol. XLIX, nr. 3, p. 434-435.

Chivu, Gh. (2000b). Grafii etimologizante in scrisul chirilic românesc din jurul anului 1800, în Ion Coteanu. In memoriam, Editura Universitaria, Craiova, p. 100-105.

Chivu, Gh. (2002a). Cei doi excesuri a amerii - o «istoriolă» romantică într-un calendar de la sfârșitul secolului al XVIII-lea, în „Limbă și literatură”, vol. I-II, p. 91-98.

Chivu, Gh. (2002b). Un experiment literar și lingvistic la sfârşitul secolului al XVIII-lea, în „Comunicările Hyperion”, Filologie, nr. 11, p. 149-158.

Chivu, Gh. (2015). Normă ideală - normă reală în scrisul literar de la sfârşitul veacului al XVIII-lea. Infinitivul lung, în: Variația lingvistică: Probleme actuale, I. Gramatică, Istoria limbii române, filologie, dialectologie, Editura Universităţii din București, p. $183-190$.

DA 1934 = Diç̦ionarul limbii române, tomul II, partea I, F-I, București, 1934 .

Gheție, I. (1967). I. Heliade Rădulescu și selecția cuvintelor românești «clasice», în „Limba română, vol. XVI, nr. 3, p. 221-223.

Gheție, I. \& Teodorescu, M. (1965). Asupra desinenței - u a pers. 3 pl. a imperfectului indicativ, în „Studii și cercetări lingvistice”, vol. XVI, nr. 1, p. 87-101.

Gheție, I. \& Teodorescu, M. (1966). Asupra desinenței - u a pers. 3 pl. a indicativului imperfect, în „Studii și cercetări lingvistice”, vol. XVII, nr. 2, p. 175-183.

Ivănescu, G. (1944-1945). Probleme capitale ale vechii române literare, în „Buletinul Institutului de Filologie Română «Alexandru Philippide»", vol. XI-XII.

Ivănescu, G. (1980). Istoria limbii române, Editura Junimea, Iași.

Kovačec, A. (1998). Istrorumunjsko-hrvatski rječnik (s gramatikom, tekstovim), Pula.

MDA 2002 = Micul dicționar academic, II, $D$-H, Editura Univers Enciclopedic, București, 2002.

Neagoe, V. (1984). Subdialectul bănăţean în Tratat de dialectologie românească, Scrisul Românesc, Craiova, p. 240-284.

Nedelcu, I. (2013). Particularități sintactice ale limbii române în context romanic. Infinitivul, Editura Muzeului Național al Literaturii Române, [București].

Papahagi, T. (1963). Diç̧̦ionarul dialectului aromân, general și etimologic, Editura Academiei Române, [București]. 
Pușcariu, S. \& Naum, T. (1941). Îndreptar și vocabular ortografic, ediția a III-a, revăzută și completată, Editura Cartea Românească, București.

Rohlfs, G. (1968). Grammatica storica della lingua italiana e dei suoi dialetit, [II], Morfologia, [Torino].

Scriban, A. (1939). Dicționaru limbii românești, Institutul de arte grafice „Presa Bună”, Iași.

Sîrbu, R. \& Frățilă, V. (1998). Dialectul istroromân, Texte şi glosar, Editura Amarcord, Timişoara.

Tiktin, H. (1906). Rumänisch-Deutsches Wörterbuch, II, Bukarest.

Ursu, N.A. (1963). Un calendar istoric-literar publicat de Paul Iorgovici, în „Limba română”, vol. XII, nr. 3, p. $283-291$.

Zdrenghea, M. (1948). Analogii în conjugarea verbului auxiliar a fi, în „Dacoromania”, nr. XI, p. 195-197. 